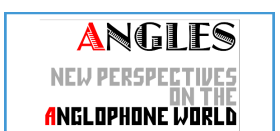

ANELOPHONE WORLI

\section{Angles}

New Perspectives on the Anglophone World

1 | 2015

Brevity is the soul of wit

\title{
Short and sweet? Structuring Humor and Morality in American Sitcoms
}

\section{Shannon Wells-Lassagne}

\section{Q OpenEdition \\ 1 Journals}

\section{Electronic version}

URL: https://journals.openedition.org/angles/2096

DOI: 10.4000/angles.2096

ISSN: 2274-2042

\section{Publisher}

Société des Anglicistes de l'Enseignement Supérieur

\section{Electronic reference}

Shannon Wells-Lassagne, "Short and sweet? Structuring Humor and Morality in American Sitcoms", Angles [Online], 1 | 2015, Online since 01 November 2015, connection on 06 June 2022. URL: http:// journals.openedition.org/angles/2096 ; DOI: https://doi.org/10.4000/angles.2096

This text was automatically generated on 6 June 2022.

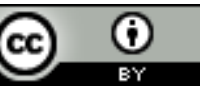

Angles est mise à disposition selon les termes de la Licence Creative Commons Attribution 4.0 International. 


\title{
Short and sweet? Structuring Humor and Morality in American Sitcoms
}

\author{
Shannon Wells-Lassagne
}

1 The situation comedy is perhaps the most successful of television's short forms, particularly in the United States. It was among the first formats to appear on the small screen, adapted directly from radio sitcoms of the period, and its popularity has never since waned in the American television landscape. This article hopes to examine how the characteristic brevity of the form, and the rapid-fire nature of its humor, is in fact coupled with a slower-paced desire for moral lessons-a soul to accompany its wit. The tension between fast and slow, between humor and morality, will be shown as both a staple of the sitcom, and an ever-evolving relationship within the genre.

\section{Sitcoms, triviality and moral conformity}

2 The sitcom has always been characterized by its limited scope: beyond its traditional 30-minute length-today the equivalent of 22 minutes to accommodate commercials-, beyond its limited stage sets used repeatedly for both financial and traditionally aesthetic reasons, the sitcom has always concerned itself with the trivial. Perhaps the most popular sitcom of recent years, Seinfeld (NBC, 1989-1998), famously insisted it was a show about nothing, about the pettiest details of everyday life, from preferred brands of food to the ethics of using handicapped parking. Though Seinfeld remains most outspoken about its obsession with trivia, the series in fact simply exaggerated one of the founding principles of the situation comedy: its humor is rooted in the mundane nature of the everyday. In blatant contrast to that other successful product of the late twentieth century, the science fiction extravaganza, there is no epic scale, no deathdefying incidents, no saving the world. ${ }^{1}$

3 However, sitcoms have also often had a tendency to conformity, to seemingly enforcing

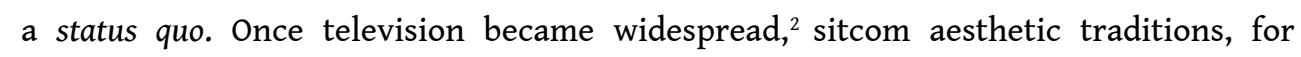


example, remained fairly similar throughout the first 50-odd years of its history, with the half-hour format, the flat lighting that allows for both close-ups and wider shots without changing lighting cues, and the requisite studio audience and recorded laugh track before multiple cameras. Likewise, the conformity of the sitcom is often social, apparent in the world presented to the viewer, which was long an idealized one, especially in terms of gender roles and middle-class social expectations. ${ }^{3}$ Exceptions existed, of course; aesthetically, we can mention the single-camera sitcoms of the $60 \mathrm{~s}$ such as The Andy Griffith Show, I Dream of Jeannie or Hogan's Heroes, though these shows still functioned within the half-hour format and with a recorded laugh track. ${ }^{4}$ Another exception to the rule of conformity from a social standpoint was The Honeymooners (CBS, 1955-1956), an early example of working-class characters living without the traditional connubial bliss. These examples are rare, however, and whatever these sitcoms' impact on television history today, ${ }^{5}$ they met with limited success at the time. It is only with the turn of the century that these traditions started to be subverted again, notably with the absence of a laugh track and a single-camera format which has been associated with increased realism in series such as Malcolm in the Middle, Curb Your Enthusiasm, or Scrubs, a fashion that continues to be common today.

In a recent work on the sitcom, Saul Austerlitz gives social justifications for conformity of early productions:

The sitcom, emerging at the tail end of the 1940s alongside the television itself, bore witness to the conformism borne of the horrors of the Second World War. A generation forged in the fire of the war sought placidity and sameness on the homefront: stable nuclear families, a nation of identically constructed Levittowns. Television was a product of the same enforced consensus. It would mirror America, not necessarily as it was, but as it should be: peaceable, middle-class, eternally unchanging. (Austerlitz 8)

5 Though clearly this ideal America was essentially only to be found onscreen, whatever the justification for orthodoxy, it manifested itself not only in the characters represented in the popular sitcoms of yore, but also in the moralities offered by these shows. Adepts of the genre are well aware of the tendency of TV parents to lecture their fictional children on the lessons to be learned from today's episode, whether it is The Brady Bunch learning the lesson (ABC, 1969-1974), or that little rascal the Beav' from Leave it to Beaver (CBS, 1957-1958; ABC, 1958-1963). A characteristic example from The Brady Bunch shows wide-eyed, innocent Cindy get her weekly dressing-down:

[Father Mike Brady puts his hand on daughter Cindy's shoulder, leads her over to a chair.]

MIKE: I think the time has come for a little one-sided discussion, here. Hop up there. [Cindy sits on the chair.] I want you to listen to me very carefully. [Slow tinkling music begins in the background as he speaks, close-up on Cindy's face as she listens solemnly, then on Mike as he resumes talking.] Cindy, you know, you've done a very bad thing with your tattling.

CINDY: Yes, Daddy.

MIKE: I know it's difficult for a little girl to know what to say, and what not to say. Grown-ups have that same problem. But you have to learn when to keep quiet. CINDY: But what if someone asks me where Mommy is? Can't I tell them? MIKE: Yes of course you can.

CINDY: Even if she's hugging the postman? [slight laughter in background] MIKE: Cindy, the point is that you are not to tattle about other people's business any more. [switch from shot-reverse shot of two actors to medium shot where they both appear] Now I mean never. 'Cause if you do, you're going to be punished. Is that clear? [back to close-up of Cindy] 
CINDY: Yes, Daddy. [medium shot of both actors]

MIKE: Good, I hope so. (The Brady Bunch, "Tattle tale," Season 2, Episode 10, 1970, 12'38"-14'30". See video below)

This media file cannot be displayed. Please refer to the online document http:// journals.openedition.org/angles/2096

The show takes this minor indiscretion very seriously, complete with musical cues that systematically signal the impending weekly lesson, close-ups of the father and daughter as he lectures, and a lack of jokes in what is nonetheless considered a situation comedy. If this was all there was to the sitcom, a rigid enforcement of aesthetic and societal norms with a morality solemnly attached, one might reasonably wonder at their popularity. The situation comedy is a genre, however, where the idea of paradox is implicit in almost every aspect. Thus, though the idea of conformity to the sitcom aesthetic was almost uniformly upheld, it was accompanied by a constant questioning of its own status as televised entertainment, both through its content-be it The Dick Van Dyke Show's protagonist (CBS, 1961-1966), a writer for a television variety show, or Lucy's constant attempts to become a famous TV star in I Love Lucy (CBS, 1951-1957) - , or through those very traditions within which it is confined, as we can see even in the somewhat limiting definition that Laurence E. Mintz gives of the genre:

Sitcoms are generally performed before live audiences, whether broadcast live (in the old days) or filmed or taped, and they usually have an element that might almost be metadrama in the sense that since the laughter is recorded (sometimes even augmented), the audience is aware of watching a play, a performance, a comedy incorporating comic activity. (Mintz 114)

The canned laughter that has come to be seen as the hallmark of traditional situation comedy is also a constant reminder that these aesthetics are just that, traditional artifices used by these comedies to induce laughter.

Likewise, the social norms that are seemingly consistently propagated by the sitcom are quickly undercut by the vast array of progressive values they suggest. One immediately thinks of the sitcoms of the 1970s, be it the many political sitcoms of producer Norman Lear-All in the Family (CBS, 1971-1979), Maude (CBS, 1972-1978), The Jeffersons (CBS, 1975-1985) -; or shows like The Mary Tyler Moore Show (CBS, 1970-1977) or Alice (CBS 1976-1985), which depicted strong working women who didn't need a man's support; MASH (CBS, 1972-1983), demonstrating the horrors and absurdities of war and the successful mixture of the comic and the tragic; or the working class and minority concerns in Sanford and Son (NBC, 1972-1977) or Good Times (CBS, 1974-1979). However, even before the 1970s, this desire to subvert the norm was implicitly present in the rash of supernatural sitcoms like The Munsters (CBS, 1964-1966), The Addams Family (ABC, 1964-1966), My Favorite Martian (CBS, 1963-1966), I Dream of Jeannie (NBC, 1965-1970) in the 60s, depicting characters who did not conform to a norm, a visible minority. Such characters were depicted even farther back with the many immigrant comedies like The Goldbergs (CBS, 1949-1951) staging Jewish characters or in Beulah (ABC, 1950-1952), the first show with an African-American lead, which made it clear that conformity could exist according to different models, and was often only an overlay of normality with underlying weirdness. 


\section{Quick humor and moral soliloquies: a paradoxical dichotomy}

9 From a structural standpoint, the moral conformity that is both characteristic of the genre and somewhat undermined within it seems in fact at odds with the very idea of the situation comedy. From The Honeymooners (CBS, 1955-1978) to Modern Family (ABC, 2009-present), show writers have relied on quick repartee and clever one-liners to keep the audience laughing. Unlike stand-up comedy, for example, which depends on extended riffing to set up a single punchline, the sitcom has traditionally demanded a much quicker output of humor, grounded in familiar situations and characters (both in the series itself and in relation to the experience of the audience). ${ }^{6}$

The rapid-fire nature of this fundamentally domestic comedy ${ }^{7}$ is in marked contrast to the very serious aspects of the morally motivated soliloquies that intend to teach a lesson to characters facing situations the audience itself might be faced with, be it an overbearing mother-in-law (Bewitched, ABC, 1964-1972) or unemployment (Roseanne, ABC, 1988-1997)-or telling tales, of course. The disparity of extended principled soliloquies and bursts of humor, of soul and wit, constitute the crux of the paradoxical art form, whose unity stems from its relatability, whether it be in terms of inside jokes about the American Zeitgeist or the familiarity of its characters and setting. I would like to examine this structural dichotomy, both as it was established by classic sitcoms of the $50 \mathrm{~s}$ and $60 \mathrm{~s}$, and as it has been redefined and subverted by more contemporary versions in shows like Community (NBC, 2009-present), The Office (NBC, 2005-2013), or Parks and Recreation (NBC, 2009-present).

One might almost say that this tension, both in mood and rhythm, can be personified by the dichotomy of characters in the sitcom. The lead characters, from solemn father Mike Brady, or any of his kin (from Father Knows Best, Ozzy and Harriet, The Andy Griffith Show and so on), or the strong but understanding women putting up with largely male hijinks (from Harriet of Ozzy and Harriet, or Laura in The Dick Van Dyke Show, to the longsuffering Jill in Home Improvement), are often straight men that act as foils to the zany sidekicks:

sidekicks were the collective deus ex machina of the sitcom, setting into action the inevitable oil slick of chaos, and the hasty cleanup crews scrubbing the floors and wiping down the counters before the onset of the next disaster. The sitcom was devoted to a certain kind of star-one whose familiarity and affability encouraged viewers to return, week after week, for our scheduled time with them. But even the most appealing sitcom stars [...] required someone off whom they could bounce their comic ideas (Austerlitz 150)

The zaniness of the sidekick made the show funny, while the leading characters were the characters with whom we were meant to identify, the characters who provided the life lessons, the emotional content that may have slowed the pace, but provided shows with their moral center. Indeed, one of the classic sitcoms, The Dick Van Dyke Show, largely separated the two aspects of the sitcom by both character and place: Rob's job as a television writer on a variety show made his workplace the locus for comedy (literally), and his colleagues the zaniest of sidekicks, while his home life, his relationship with wife Laura and son Richie, were often the focus of the lesson to be learned that week, a slower-paced and more emotional story. The antithetical nature of comedy and emotion, of quips and extended monologues, was both confirmed and 
subverted by a recurring story of Rob's fellow comedy writer Sally, who is incapable of domestic bliss largely because of her inability to stop cracking jokes:

[Laura and Rob are seated on their couch at home with Sally's blind date, Laura's cousin Thomas, who is a lab assistant.]

THOMAS: I'm afraid I'm a little nervous about this meeting.

LAURA: Well Thomas, there's nothing to be nervous about, is there, Rob?

ROB: [Grimacing, then shaking his head excessively; laughter heard in the background] No, no. I mean... [uneasily] Why be nervous? [laughter. The doorbell rings, and both Rob and Laura spring up anxiously. Laughter]

LAURA: [loudly] There she is! [Laughter. They run to the door, then each turns away from it and pushes the other towards it, neither being willing to open the door and begin the blind date. Laura inhales deeply to calm herself, and opens the door. Laughter throughout. Laura speaks with excessive (and thus clearly feigned) enthusiasm] Hi, Sally!

SALLY: Hi. [speaking very rapidly, all in one breath] Here's a plastic spaceship for Richie, and a $5 \mathrm{lb}$. box of candy for you, and let's not waste any more time, where is he? [Raucous laughter. She marches from the door to the couch where Thomas is waiting. Exaggeratedly polite] How do you do, I'm Sally Rogers. Are you still single? [Laughter]

THOMAS: Am I still what?

LAURA: Sally, this is my cousin, Thomas Edson.

SALLY: [takes a beat, looks consideringly over at Thomas] Thomas... Edson? [camera on Rob, who abruptly stops smiling, realizing the joke that is coming]

ROB: Oh, no!

SALLY: Well, you did a great job on that light bulb, Tom! [laughter. Camera cuts to Rob, who closes his eyes in consternation.] I wanna talk [she pulls Thomas closer so that she can speak directly into his ear] I said I wanna talk about [end of line indecipherable underneath laughter from audience. Applause]

ROB: Not Edison. Edson.

SALLY: Oh, Edson. I thought he looked a little young for an old inventor. [she pokes him in the stomach and laughs (as does the audience)]

THOMAS: [reaching behind him, pulling out his hat] I brought you these.

SALLY: [looks at it, then dons the hat, shrugging] It's a bit small... [laughter]

THOMAS: I meant these. [He picks up a bouquet of flowers and offers them to her.]

SALLY: Oh. [She takes the flowers, and Thomas removes his hat from her head. Laughter] Oh, yes. Oh, of course! [She puts the flowers on her head in lieu of the hat] Oh, that's a much better fit. [Laughter]

ROB: Sally, wouldn't you like to sit down?

SALLY: Thank you.

LAURA: How about an hors d'œuvre?

SALLY: No, thank you, this [slapping Thomas's knee affectionately] is my little hors d'œuvre. [laughter. Camera cuts to Rob, biting his finger in anxiety]

ROB: Wouldn't you like a piece of herring?

SALLY: No thanks, it gives me hives.

THOMAS: Herring gives you hives? Did your doctor ever tell you to try Chlorachlosine hydrochloride?

SALLY: No, does it taste like herring? [laughter]

THOMAS: No, it's a pill.

SALLY: Oh, wonderful-I'll have a plate of herring pills! [laughter. Camera cuts to Rob, then Laura, both laughing uncomfortably]

THOMAS: Actually it's a pill designed to relieve an allergic symptom. You see, Miss Rogers, your body-

SALLY: Well if you're going to talk about my body, you'd better call me Sally! [laughter]

THOMAS: I didn't mean your body, Miss Rogers, I was talking about the human body. 
SALLY: Human body-what am I, a kangaroo!?! [laughter]

THOMAS: No, I didn't mean that at all! I hope you don't think I'd presume-

ROB: [abruptly standing up] Well, it's getting late [making a point of checking his watch] You see, it's-Time flies when you're having fun, doesn't it? [laughter] Come on, Sal, I'll drive you home. [he starts to pull Sally up, only to have Laura pull him back]

LAURA: You comedy writers! I'll just... uh... see to dinner! [she walks away, towards the kitchen]

ROB: [laughing] Excuse me, I'll see it with her. [he runs backwards, still facing Sally and Thomas, following Laura to the kitchen. Laughter. Cut to kitchen, Laura and Rob entering]

LAURA: All right, don't say it, don't say it.

ROB: It's not fair. $95 \%$ of the time you're right-when you're wrong will you please give me a chance to say so?

LAURA: All right, say so-but I may not be wrong.

ROB: Aww, honey, did you see what she's doing to that poor guy out there?

LAURA: I know, it's pretty awful, but maybe she'll calm down during dinner.

ROB: Gosh, I hope so. Any other guy would have punched her in the nose! (The Dick

Van Dyke Show, "Sally and the Lab Technician," Season 1, Episode 3, 1961, $11^{\prime} 30$ "'-14'43". See video below. $)^{8}$

This media file cannot be displayed. Please refer to the online document http:// journals.openedition.org/angles/2096

When Laura sets Sally up with her cousin, the intrusion of the comic into the home setting is a source of stress for everyone (except the unsuspecting date). You can notice that the pace changes dramatically between Sally's incessant wisecracking and the quiet moment between the lead characters as they discuss the situation and comment on its impropriety afterwards, changing both characters and location to signal a change in tone (from pure comedy to a more serious bent).

When Sally later recognizes her inability to stop wisecracking-an inability that is both personal to the character, and of course structurally necessary to the very way the show functions-, emotion intrudes into the workplace, subverting the established dichotomy between the workplace, and Sally's association with pure comedy, and the home, with Laura, the wife, a locus for emotion and more subdued comedy.

SALLY: Hey, I sure had a wonderful time at your house last night, Rob.

ROB: Aw, I'm glad, Sal.

BUDDY: Hey, Rob told me you were in delightful form last night!

ROB: I told him you were the life of the party.

SALLY: Oh, boy, that's me... old life-of-the-party Sal. Jokes for any occasion. [Cut to

Rob, looking concerned]

BUDDY: So tell me, how'd you like Laura's cousin?

SALLY: [looking down solemnly, then briefly up] I don't know.

BUDDY: Whaddya mean, you don't know?

SALLY: Well, he and I didn't get to talk very much. [laughter]

BUDDY: Come on, there were only the four of you!

SALLY: Well, I don't-

ROB: I think Sally means that Thomas didn't say much. [Sally nods, still looking down.]

SALLY: I didn't give him much chance to. Rob, are you sure there were no phone calls for me? [...] [musical cue, serious music] Well, fellas, whaddya say, get to work? ROB: No, Sal, no use jumping right into it, if you'd like to wait for coffee, and take a look at the newspaper... 
BUDDY: Yeah, why don't we have one of those breakfast breaks, say two, three hours? [laughter]

SALLY: What's the matter with you two?

BUDDY: We're just trying to pep you up. You look like a cheerleader for an accident. [laughter]

ROB: We just thought maybe you didn't feel like making any jokes today.

SALLY: Jokes? Oh, I wanna make jokes. Gotta make jokes. There's nothing I love more than making jokes. Didn't I make a bunch of great jokes last night, Rob? Oh boy, Buddy, you should have seen me. I was a small riot. I was so funny... I was so funny, Cousin Thomas laughed so hard, he almost smiled. [looks down, fighting back tears] I was so doggone funny... [she slams palms on desk] I couldn't stand myself! [she flees the room, serious music continuing throughout] (The Dick Van Dyke Show, "Sally and the Lab Technician," Season 1, Episode 3, 1961, 17'35"-19'47". See video below.)

This media file cannot be displayed. Please refer to the online document http:// journals.openedition.org/angles/2096

Again we can notice a change of pace as Sally acknowledges her failings and makes explicit the idea that comedy is contrary to emotion: as we get to the moral of the story, the pace slackens considerably, the character speaks more and more slowly, the musical cue reinforces the seriousness of the moment, and the clip has only one clear joke (signaled as such by the laugh track). Though we may be surprised by the unexpected locale and character, both of which have previously been associated with pure comedy, to represent this emotional realization, the change of rhythm is invariable, underlining the dichotomy between slow-paced emotion with longer dialogue versus fast-paced quips and short repartee. In an interview by Dick Van Dyke (1998), the actor even suggested that this dichotomy was incarnated behind the scenes as well: Carl Reiner was the "master of comedy", while Sheldon Leonard was the "master of storytelling", and they would often be at odds.

\section{Picking up the pace and lightening the tone}

However, as the sitcom evolved, writers sought to pick up the pace and increase the comic output of their shows. One of the ways they chose to do that is by increasingly featuring outrageous secondary characters who could always reliably garner a laugh. Whether it be Taxi (ABC 1978-1982, NBC 1982-1983), whose straight man Alex (Judd Hirsch) was slowly pushed into the wings by secondary characters like Latka (Andy Kaufman) and Iggy (Christopher Lloyd), or Happy Days (ABC 1974-1984), where the family fun of the Cunningham family gave way to the increasing importance of Henry Winkler's "The Fonze", the sidekicks slowly took over the screens.

17 As such, one of the results of this attempt to increase pacing was the creation of ensemble shows where there is no clear-cut lead, no straight man with whom the viewer is supposed to sympathize, but rather a group of quirky individuals. One could argue that no one character acts as straight man to the others in Friends (NBC, 1994-2004), for instance, especially in its later seasons, and Seinfeld definitely eschewed any sane character, preferring to demonstrate the neuroses of each member of the crazy quartet. This trend perhaps culminated with The Big Bang Theory (CBS, 2007present), where the ensemble is a cast of misfits-those who argue Penny is "normal" 
have forgotten that the aspiring actress-cum-waitress is played for laughs both in her lack of career prospects and her inability to understand geek culture.

The importance of the lesson drawn from the events of the sitcom was also affected by this desire to pick up the pace: increasingly sitcoms came to attempt to inject the morality with some form of humor, to limit the change of pace and tone that we've seen in the examples of both The Brady Bunch and The Dick Van Dyke Show. Thus, the 80s and 90 s featured shows whose morality was not undermined in content, but whose tone could be lightened through context or characterization. In Home Improvement (ABC, 1991-1999), for example, neighbor Wilson is a fount of knowledge for Tim, the clueless lead-to the extent that the miscommunication between the two is a source of comedy even as the moral itself remains intact:

[Wilson is hidden behind a telescope, where he is admiring the night sky; on the other side of the fence, Tim is putting away a garden hose.]

TIM: I don't know what gets into me. I had a simple project, I had to replace a sink. Then I rip out the wall, boom, bam, I got pipes everywhere, water flowing out, I got water mains shut off-I can't stop this.

WILSON: Well, Tim, you're probably just responding to the visceral male urge to create. [laughter]

TIM: Visceral... vis-vis... visceral?

WILSON: Let's just say, gut need.

TIM: Yeah, that's exactly what it feels like, it's a visceral gut thing. [laughter] I like to create, Wilson-everything I do, I want to make bigger and better.

WILSON: [now facing Tim, but hidden behind fence] Well, Tim, this obsessive desire to create partly happens because men feel inferior to women.

TIM: [in utter bewilderment] Huh?

WILSON: It's because we can't bear children.

TIM: Nah, I don't mind the boys that much. [laughter]

WILSON: No no no, Tim. What I mean is... women can give birth and we can't. [...] Perhaps one of the reasons you get so involved with your projects is that you want to create something as wondrous as human life.

TIM: That's a neat thought, Wilson. But the way this project is going, I think giving birth would have been easier. [...] [Tim explains Wilson's reasoning to his wife Jill] JILL: I'm sorry I got mad and left.

TIM: It's OK [...] I can't give birth. [laughter] It's a problem in my gut with a viscral [sic] thing [laughter]. It's really, really, hard to explain.

JILL: Don't try. (Home Improvement, "Bubble, Bubble, Toil and Trouble", Season 1, Episode 9, 1991, 18'-20’50". See video below.)

This media file cannot be displayed. Please refer to the online document http:// journals.openedition.org/angles/2096

The neighbor-philosopher Wilson is a figure of abstraction-his face is always hidden in the series-and his very conceptual reasoning for Tim going overboard on his remodel of their bathroom provides humor, first through its excess, and then through its garbled reinterpretation by Tim. The show retains the moral center of the series, the long speech, but mines that speech for laughter to increase the pacing of the episode.

Another show from the 1980s and 90s, Designing Women (CBS, 1986-1993), also makes an individual character the mouthpiece for the majority of the series' moral lessons: the cast features four women working at an interior design company in Atlanta, Georgia, but it is Julia Sugarbaker (Dixie Carter) whose fiery speeches provide the moral center: 
RAY DON: Excuse me, but you ladies look like you're in need of a little male companionship.

JULIA: Trust me when I tell you that you have completely misassessed the situation at this table.

RAY DON: Aaah... sense of humor, I like that. [...] Allow me to introduce myself. My name is Ray Don Simpson.

JULIA: There's no need for introductions, Ray Don, we know who you are.

RAY DON: You do?

JULIA: Of course. You're the guy who's always where women gather or try to be alone. You want to eat with us when we're dining in hotels, you want to know if the book we're reading is any good, or if you can keep us company on the plane. [Ray Don attempts to respond, and Julia continues, undaunted] And I want to thank you, Ray Don [laughter], on behalf of all those women in the world for your unfailing attention and concern. But read my lips, and remember, as hard as it is to believe, sometimes, we like talking just to each other, and sometimes, we like just being alone. [applause]

RAY DON: OK, I can take a hint. [he rises from the table] You want a little girl talk. I'll just make a couple of phone calls, be right back. (Designing Women, Pilot, Season 1, Episode 1, 1986. 13'00"-15'16". See video below.) $)^{9}$

This media file cannot be displayed. Please refer to the online document http:// journals.openedition.org/angles/2096

This monologue was from the pilot episode of the series, and established both the form and content of the series to come: the idea of women speaking amongst themselves without the need for a man was a recurrent one in the show, given that the focus was always on the friendship of the four women and not their male love interests, and Julia delivered at least one sermon per episode. As in Home Improvement, there are obvious efforts made to keep the moral lesson from slowing the pacing of the show. Indeed, Dixie Carter's dramatic and rapid-fire delivery does not really deaden the pace; the desultory conversation that precedes it means that the moral does not cause delivery to flag, but arguably actually increases the tempo, while her feigned civility and veiled mockery induce laughter at the expense of her hapless victim (who has been carefully depicted as a misogynist villain entirely worthy of such scorn). Clearly, the tension between humor and emotion, between monologue and one-liner, was identified and problematized by these late twentieth-century sitcoms.

Other aspects of the traditional structure of the sitcom have also had an effect on the quick pacing of contemporary shows. The new popularity of single-camera sitcoms may not appear to necessarily impact their pacing, but an article in The Atlantic demonstrates the sharp contrast in the number of jokes per minute between the shows with multiple cameras and the new, single-camera fictions:

-1. 30 Rock 7.44

-2. New Girl 7.11

-3. Parks and Recreation 6.97

- 4. The Office 6.65

- 5. Brooklyn Nine-Nine 6.59

- 6. Friends 6.06

- 7. The Big Bang Theory 5.80

- 8. Modern Family 5.68

- 9. Family Guy 5.20

•10. South Park 5.03 
-11. Frasier 4.09

-12. Curb Your Enthusiasm 3.41 (Visram 2014)

It is significant that the top five with the rapid-fire delivery of jokes are all singlecamera sitcoms, while more traditional sitcoms with laugh tracks, like Friends, The Big Bang Theory, or Frasier, all score somewhat lower. The author suggests that pacing differs significantly according to the type of humor attempted, but from a more mechanical standpoint, one could simply say that a laugh track automatically slows down the pace. ${ }^{10}$ Even in more recent series such as Friends which actually speed up the action by having a third plot each episode,$^{11}$ an excerpt of an episode without the laugh track shows how the actors must delay their reactions to insert the studio audience and pre-recorded laughs, making these moments of "dead air" sound stilted, and revealing the slower pace of the traditional laugh-track sitcom ("The One after Vegas", Season 6, episode 1, 1999, see video below).

This media file cannot be displayed. Please refer to the online document http:// journals.openedition.org/angles/2096

\section{Undermining the idea of a moral}

Beyond this, there has been a tendency to not only mine the moral lesson for humor, as in the attempts of the 80s and 90s to inject the moral with comedy, but to slowly undermine it, questioning its very basis. As the leading characters have become less prevalent in the current landscape of comic television and the antics of characters who would formerly be sidekicks take center stage, the very idea of a moral, a life lesson, has begun to be questioned. When Penny becomes addicted to video games in The Big Bang Theory, for instance, Leonard's efforts to teach Penny a life lesson simply make him the butt of the joke, not the moral authority:

LEONARD: Okay, um, here's the thing, um, sometimes people, good people, you know, they start playing these games and they find themselves through no fault of their own, you know, kind of, addicted.

PENNY: Yeah, get to the point, I'm about to level up here.

LEONARD: Well, i-i-i-it's just if a person doesn't have a sense of achievement in their real life it's easy to lose themselves in a virtual world where they get a false sense of accomplishment.

PENNY: Yeah, jabber jabber jabber, okay boys, Queen Penelope's back online. (Big Bang Theory, "The Barbarian Sublime", Season 2, Episode 3, 2008)

As is its wont, The Simpsons goes even further in questioning the very idea of a didactic lesson to be gleaned from the family's antics. In an episode entitled "Blood Feud", the characters attempt vainly to find a moral to their adventures:

MARGE: The moral is, a good deed is its own reward.

BART: We got a reward. The head is cool.

MARGE: Well, then. I guess the moral is, no good deed goes unrewarded.

HOMER: Wait a minute. If I hadn't written that letter-we would've gotten nothing.

MARGE: Well. The moral is, the squeaky wheel gets the grease.

LISA: Perhaps there is no moral.

HOMER: Exactly! Just stuff that happened. (The Simpsons, "Blood Feud", Season 2, Episode 22, 1991) 

Greatest Boss," Michael Scott, offers the traditional moral speeches expected in that role, but is so morally ambiguous as to undercut his point-which of course makes it funny, but also less moral. In the episode entitled "Diversity Day" (Season 1, Episode 2, 2005), Michael's attempt at conducting a seminar on racial sensitivity is doubly undermined, first because it turns out to be a management initiative ordered in reaction to his own actions (offending the office staff with an ill-conceived rendition of Chris Rock's stand-up comedy), and then because his suggested activity actually fosters racial stereotypes (asking his workers to treat each other as if they were members of a given race). Whatever his intentions, Michael Scott fails as a moral authority, and it is that very failure that inspires laughter.

Another recent sitcom, Community, also bucks the trend of an ensemble of quirky characters. It has a clear lead character who might provide moral leadership: Jeff Winger is handsome, cool, and intelligent-but he's also largely amoral, returning to the titular community college to get the Bachelor's degree he lied about having in his previous life as a lawyer. The pilot episode features Jeff explaining "I discovered at a very early age that if I talk long enough, I can make anything right or wrong. So either I'm God, or truth is relative. And either way, Boohyah!" (Community, "Pilot", Season 1, Episode 1, 2009) In other words, though Jeff may be the speaker of monologues in the show, he is clearly not the moral center. Another episode thematizes the idea that these moral life lessons, complete with rousing soundtrack, are essentially empty, interchangeable, and they become a source of laughter rather than a source of reflection:

JEFF: [Cue inspirational music] Look, we've known each other for almost two years now. And in that time, I've given a lot of motivational speeches.

[cut to group in haunted house, cobwebs all over them]

But they all have one thing in common. They're all

[cut to group with Pierce on his knees, a man with a gun to his temple]

different. These drug runners aren't going to execute Pierce because he's racist.

[cut to group in front of a steam engine]

It's a locomotive that runs on us.

[cut to group in front of a wooden fence and lake, carrying rifles]

And the only sharks in that water

[cut to haunted house]

are the emotional ghosts that I like to call fear

[cut to Caesar Salad day at the cafeteria]

anchovies

[cut to camping trip]

fear

[cut to group in an asylum, all in strait jackets]

the dangers of ingesting mercury.

[cut to group in their underwear in front of a rundown motel]

Because the real bugs aren't the ones in those beds.

[cut to Caesar Salad Day in the cafeteria]

There's no such thing as a free Caesar salad, and even if there were

[cut to the group in Abed's dorm room, all wearing capes]

The Cape still might find a second life on cable, and I'll tell you why:

[cut to the group with drugrunners, in Spanish]

el corazon del agua es verdad/the heart of water is truth

[cut to group with shotguns in front of lake]

that water is a lie!

[cut to group in asylum] 
Harrison Ford is irradiating our testicles with microwave satellite transmissions! [back to study room]

So maybe we are caught in an endless cycle of screw-ups and hurt feelings. But I choose to believe it's just the universe's way of molding us into some kind of supergroup.

TROY: Like the Travelling Wilbury's.

JEFF: Yes, Troy, like the Travelling Wilbury's of pain. Prepared for any insane adventure life throws our way. And I don't know about you, but I'm looking forward to every one of them."

[The different members of the group murmur "that's nice", "Aww, Jeff", and all move back to hug Jeff.] (Community, "Paradigms of Human Memory", Season 2, Episode 21, 2011. 16'30"-18')

This media file cannot be displayed. Please refer to the online document http:// journals.openedition.org/angles/2096

The tension between quick repartee and long monologues is but one aspect of the many revolutions taking place in sitcoms in particular and in television in general, but it exemplifies the fine line that comedy walks-it must be familiar enough in content and form to allow the audience to identify with the characters or the situations, and it must provoke and innovate enough to surprise and delight the same audience to laughter. An episode of Scrubs, another single-camera fiction that eschews the laugh track in favor of more rapid-fire jokes, seems particularly relevant here. In one episode, lead character J.D., ER doctor and sitcom fanatic, meets a writer from the sitcom Cheers-and discovers the man has cancer. His commentary suggests that whatever the changes, the sitcom acknowledges its roots, and its need, above all, to entertain:

J.D.: There are moments when we all wish life was more like a sitcom [...] unfortunately, around here things don't always end as neat and tidy as they do in sitcoms [...] at times like that, it's comforting to know there's something to pick your spirits up. (Scrubs, "My Life in Four Cameras", Season 4, Episode 17, 2005)

\section{Short and sweet?}

Whether it is classic or contemporary comedy, with a laugh track and a studio audience or without, the sitcom exists to make us feel good for the next half hour. And ultimately, the situation comedy does so by making us care for the characters who make us laugh. If the certainty of the all-knowing monologue is being questioned in a postmodern world, if it is revealed to be hollow and self-contradictory, as in Community, the emotion it engenders is no less necessary to bring the group and the audience back together. Whether there is a formal monologue or not, the push and pull between joke and emotion, between banter and confidences, between short and long, remains a structural force in TV sitcoms. 


\section{BIBLIOGRAPHY}

\section{Books and articles}

Austerlitz, Saul. Sitcom: A History in 24 episodes from I Love Lucy to Community. Chicago: Chicago Review Press, 2014.

Corke, Mike. "Sitcom: Why Audiences Laugh". The British Comedy Guide website. [archived: https://web.archive.org/web/20160317140625/http://www.sitcom.co.uk/writers/ why_audiences_laugh.shtml]

Dalton, Mary and Linder, Laura R. The Sitcom Reader: America Viewed and Skewed. Albany: State University of New York Press, 2005.

Mintz, Laurence E. "Situation Comedy”. TV Genres: A Handbook and Reference Guide. Ed. Brian G. Rose and Robert S. Alley. Westport, CT: Greenwood, 1985. 107-129.

Owen, Rob. GenX TV, The Brady Bunch to Melrose Place. Syracuse, NY: Syracuse UP, 1997.

Sanes, Ken. "Sitcoms and the Liberating Power of Sadism", March 2014. https:// transparencynow.com/sitcom.htm

Tredy, Dennis. “The Origins of the TV Sitcom: Transgressional Comedy in the Early 1950's”. Sitcom Masterclass, Université de Rouen, 30 January 2015.

Van Dyke, Dick. “Dick Van Dyke discusses ‘The Dick Van Dyke Show’ scripts EMMYTVLEGENDS.ORG”. Interviewed by Lee Goldberg, 8 January 1998. https:// www.youtube.com/watch?v=CG7j2foq67g

Visram, Talib. "The One Where I Counted the Jokes in Popular Sitcoms", The Atlantic, 28 November 2014. https://www.theatlantic.com/entertainment/archive/2014/11/jokes-perminute-sitcom-ratings-link/382734/

\section{TV shows}

30 Rock (NBC, 2006-2013).

The Addams Family (ABC, 1964-1966).

Alice (CBS 1976-1985).

All in the Family (CBS, 1971-1979).

The Andy Griffith Show (CBS, 1960-1968).

Beulah (ABC, 1950-1952).

Bewitched (ABC, 1964-1972).

The Big Bang Theory (CBS, 2007-present).

The Brady Bunch (ABC, 1969-1974).

Brooklyn 99 (Fox, 2013-present).

Community (NBC, 2009-present). 
Curb Your Enthusiasm (HBO, 2000-2011).

Designing Women (CBS, 1986-1993).

The Dick Van Dyke Show (CBS, 1961-1966).

Father Knows Best (CBS, 1954-1960).

Frasier (NBC, 1993-2004).

Friends (NBC, 1994-2004).

The Goldbergs (CBS, 1949-1951).

Good Times (CBS, 1974-1979).

Happy Days (ABC, 1974-1984).

Hogan's Heroes (CBS, 1965-1971).

Home Improvement (ABC, 1991-1999).

The Honeymooners (CBS, 1955-1978).

I Dream of Jeannie (NBC, 1965-1970).

I Love Lucy (CBS, 1951-1957).

The Jeffersons (CBS, 1975-1985).

Leave it to Beaver (CBS, 1957-1958; ABC, 1958-1963).

Malcolm in the Middle (Fox, 2000-2006).

The Mary Tyler Moore Show (CBS, 1970-1977).

MASH (CBS, 1972-1983).

Maude (CBS, 1972-1978).

Modern Family (ABC, 2009-present).

The Munsters (CBS, 1964-1966).

My Favorite Martian (CBS, 1963-1966).

The Office (NBC, 2005-2013).

Ozzy and Harriet (ABC, 1952-1966).

Parks and Recreation (NBC, 2009-present).

Roseanne (ABC, 1988-1997).

Sanford and Son (NBC, 1972-1977).

Scrubs (NBC, 2001-2009, ABC, 2009-2010).

Seinfeld (NBC 1989-1998).

South Park (Comedy Central, 1997-present).

Taxi (ABC 1978-1982, NBC 1982-1983). 


\section{NOTES}

1. This association was borrowed from Ken Sanes (2014): "Sitcoms, on the other hand, draw us into a more modest world, descended not from mythology, and day and night dreams, as is science fiction, but from comedy of manners, vaudeville and our tacit perceptions of everyday life. Their theme is our inability to conquer our petty desires as we go about the minor tasks of the day."

2. The very early days of television were largely broadcast only to the Northeast of the United States (primarily New York City), and included experimentation in both form and content (breaking the fourth wall, questioning the domestic status quo, blurring boundaries between the sitcom and the variety show, etc.) that would only reappear in the 1990s and 2000s. See Dennis Tredy's talk on the subject (2015).

3. No doubt the normative nature of these representations and their tendency towards moral lessons is due to pressure from the Federal Communications Commission, which began debating the possible immorality of television and its need for strict monitoring and control in 1952. A copy of the FCC report is available online: https://apps.fcc.gov/edocs_public/attachmatch/ DOC-308672A1.pdf.

4. This ended in the 1970s with the success of All in the Family until the turn of the century saw a return of the single-camera.

5. Though The Honeymooners and its brethren, like The Goldbergs, with working-class Jewish protagonists, insist on forgoing a certain number of what will later become sitcom traditions (a live audience for The Goldbergs, and a working-class setting for both), these sitcoms basically performed for a largely urban audience, and met with severe difficulties in terms of longevity and audience (and studio) reception. The Honeymooners only ran for one year as an independent show, while The Goldbergs ran for two before being dropped for political reasons and only being taken back on as a shorter sketch (15 minutes) under a different name and with less troublesome actors (Dalton \& Linder 19).

6. See for example Mike Corke's analysis of the phenomenon in "The British Comedy Guide": "What should become clear is that what we are not laughing at are 'jokes' in the way we normally recognise and understand them. [...] A joke lasting one to two minutes comprises of a lead up and a punch line. The lead up is usually listened to in silence and the punch line triggers the laughter. A good stand-up comedian may evoke a few titters on the way (he might pull faces, speak in a funny voice, fall over, etc.) but the really worthwhile laugh always comes at the end. He does quite well if he can bring about, on average, just over one significant laugh per minute or tell four, maybe five, good jokes in a six-minute spot. For successful situation comedy the laughter frequency needs to be much higher, at between three or four per minute. Analysis of a 30-minute episode of a well-known series revealed 90 points of humour comprising 56 chuckles and 34 extended laughs."

7. Whether the sitcom takes place in the home or the workplace, it always involves a cast of characters that become a tight-knit group, a family by blood or by circumstance, and their concerns are largely everyday concerns, from Happy Days (ABC, 1974-1984), where the entire group of young characters comes to consider Mrs. Cunningham as their erstwhile mother, to Brooklyn 99 (Fox, 2013-present), which parodies cop dramas but limits itself to very ordinary crimes, and where lead character Jake Peralta clearly sees his chief as a father figure.

8. Given that the focus will be on dialogue and pacing, I encourage readers to watch the excerpt for themselves.

9. As delivery of the lines is crucial to understanding the effect on pacing, I recommend viewing the excerpt directly.

10. Though this does not necessarily mean that it is less successful-the highest audience numbers belong to the shows that are dead center, i.e. The Big Bang Theory and Friends. 
11. "The producers of Friends prefer that each episode has three storylines, which differs from most sitcoms that feature just two stories. Because of this decision, there are more scenes, but they're shorter, just like E.R., Friends's Thursday night companion." (Owen 113)

\section{ABSTRACTS}

Seinfeld (NBC, 1989-1998), perhaps the most popular sitcom of recent years, famously insisted it was a show about nothing, about the pettiest details of everyday life. Though Seinfeld remains most outspoken about its obsession with trivia, the series in fact simply exaggerated one of the founding principles of the situation comedy: its humor is rooted in the mundane nature of the everyday. This focus on minutiae extends to the very nature of its humor; from The Honeymooners (CBS, 1955-1978) to Modern Family (ABC, 2009-present), show writers have relied on quick repartee and clever one-liners to keep the audience laughing. Interestingly, the rapid-fire nature of this fundamentally domestic comedy is in marked contrast to the very serious aspects of the sitcom, the morally motivated soliloquies that intend to teach characters a lesson. The disparity of bursts of humor and extended principled soliloquies constitute the crux of this paradoxical art form, whose unity stems from its relatability (whether it be in terms of inside jokes about the American Zeitgeist or the familiarity of its characters and setting). I would like to examine this structural dichotomy, both as it was established by classic sitcoms, and as it has been redefined and subverted by more contemporary versions.

Seinfeld (NBC, 1989-1998), dont le sitcom éponyme est sans doute l'un des plus populaires de ces dernières décennies, avait l'habitude de dire que c'était une émission sur rien, sur les détails insignifiants de la vie quotidienne. Senfield se manifeste avant tout par cette obsession pour ce qui est futile, mais en réalité, cette série ne fait qu'exacerber l'un des principes fondateurs du comique de situation, et son humour est ancré dans la banalité du quotidien. On retrouve ces aspects dans l'humour de ces émissions, et depuis The Honeymooners (CBS, 1955-1978) jusqu'à Modern Family (ABC, 2009-présent), les scénaristes se sont appuyés sur le sens de la répartie pour faire rire les spectateurs. De fait, il existe un écart entre les répliques comiques débitées à toute allure et les aspects plus sérieux du sitcom, à savoir les soliloques à teneur morale qui ont pour objet de donner une leçon aux personnages. La disparité entre l'humour et les principes moraux des longs soliloques constitue le cœur de cette forme artistique paradoxale, dont l'unité provient de sa « relatabilité » (qu'il s'agisse de blagues de connivence sur le Zeitgeist américain ou de la connaissance des personnages et du contexte). Cet article analyse cette dichotomie structurelle, s'intéressant à la fois à la manière dont les sitcoms classiques l'ont établie et à la manière dont elle a été redéfinie et subvertie par ses avatars contemporains.

\section{INDEX}

Keywords: sitcom, television, comedy, one-liners, moral, rhythm, humour

Mots-clés: sitcom, télévision, comédie, réplique, morale, rythme, humor 


\section{AUTHOR}

\section{SHANNON WELLS-LASSAGNE}

Shannon Wells-Lassagne is a lecturer at Université de Bretagne Sud. She specializes in film and TV adaptations. She is the author of Étudier l'adaptation filmique (Presses Universitaires de Rennes) (with Laurent Mellet), and has edited (with Delphine Letort) Premières pages, premiers plans, and (with Ariane Hudelet) Screening Text (McFarland), De la page blanche aux salles obscures (Presses Universitaires de Rennes). She has edited special issues of Interfaces (Expanding Adaptations, with Ariane Hudelet), GRAAT (Television and Narratology, with Georges-Claude Guibert). She has published articles in Screen, Critical Studies in Television, The Journal of Adaptation in Film and Performance, and Irish Studies Review. Contact: shannon.wells-lassagne [at] @univ-ubs.fr 